\title{
14. Översättningens plats inom utbildning och forskning i romanska språk
}

\section{Cecilia Alvstad, Elisabeth Bladh, Olof Eriksson \& Mårten Ramnäs}

Översättning har traditionellt sett haft en framträdande roll inom undervisning i romanska språk, även om den kommunikativa metoden på senare tid något trängt undan användandet av översättning som språkdidaktiskt hjälpmedel i klassrummet. Vad gäller forskning är det framförallt i franska som översättningsvetenskapligt inriktade studier bedrivits. I det här kapitlet behandlas översättningens plats inom utbildning och forskning i romanska språk ur tre perspektiv. I en första avdelning (14.1) diskuterar Mårten Ramnäs användningen av översättning som didaktiskt hjälpmedel i samband med språkfärdighetsmomentet. Därefter redogör Olof Eriksson för dess lämplighet som ämne för uppsatsskrivning (14.2). Avslutningsvis resonerar Cecilia Alvstad och Elisabeth Bladh kring den översättningsvetenskapliga forskning som bedrivs av forskare i romanska språk i Sverige (14.3).

\section{1 Översättning som pedagogiskt verktyg}

Mårten Ramnäs

Översättning som en del av språkundervisningen har en lång tradition, både på universiteten och inom ungdomsskolan, men har även länge pekats ut som ett problem, vilket gjort att översättning numera förekommer i betydligt mindre omfattning i de flesta svenska språkutbildningar. På flera lärosäten finns idag kurser och hela utbildningsgångar i franska (och andra moderna språk) som är helt fria från svenska. I vissa fall är svenskan inte ens ett krav för att bli antagen till utbildningen.

Översättningens kräftgång som pedagogiskt verktyg torde i första hand kunna förklaras av en förändrad syn på språkundervisningens mål, en ny kunskapssyn och framväxten av nya undervisningsmetoder. Översättningen förknippas med äldre tiders språkundervisning och har till och med fått ge sitt namn åt den så förhatliga "Grammatik- och översättningsmetoden", som var rådande långt in på 1900-talet (Tornberg 2015: 34-37). Den kommunikativa språkundervisningen är idag helt förhärskande inom ung- 
domsskolan, och präglar i viss mån även universitetets språkutbildningar (där ju blivande ungdomslärare utbildas). Med sin betoning på autentiskt material och kommunikation på målspråket $\mathrm{i}$ undervisningen har denna metod bidragit till att översättningen hamnat i skamvrån.

Även om den rådande ideologin i Sverige och de flesta andra länder officiellt bannlyser modersmålet i språkundervisningen förekommer översättning trots allt fortfarande i många undervisningssituationer, både formellt och informellt (Cook 2010: 7; Källqvist et al. 2017). Många lärare har därför en tvetydig hållning till översättning - de använder den i undervisningen, men vill inte gärna kännas vid att de verkligen gör det.

Ett vanligt förekommande exempel på översättning i undervisningen är översättningsekvivalenter i ordlistor. Erfarna lärare vet att det är mycket effektivt att ge en översättningsekvivalent när ett ord ska förklaras eller definieras första gången, vilket också bekräftas av ordinlärningsforskare: "studies comparing the effectiveness of various methods for learning always come up with the result that an L1 translation is the most effective [...] When the use of an L1 translation is combined with the use of word cards for the initial learning of vocabulary, then learners have a very effective strategy for speeding up vocabulary growth" (Nation 2005: 3-4).

Att studenter på olika sätt använder sig av sitt modersmål när de lär sig ett främmande språk är alltså helt naturligt och önskvärt - det kommer att ske alldeles oavsett påbud om att endast målspråket skall används. Att knyta an till det redan kända är en snabb och effektiv väg till kunskap (Butzkamm 2003). Istället för att peka ut modersmålet som ett problem i språkundervisningen menar jag därför att man istället bör se det som en tillgång.

Översättningsövningar kan hjälpa studenter att reflektera metalingvistiskt över skillnader mellan modersmålet och målspråket på olika plan. Olof Eriksson fokuserar på just översättningsanalysens möjligheter, i synnerhet som ämne för uppsatser på kandidat-, magister- och masternivå. Jag kan helt instämma i Olof Erikssons resonemang. Denna typ av uppsatser har inte bara god potential som vetenskapliga uppsatsämnen, men kan även bidra till att utveckla studenternas språkfärdighet genom en större medvetenhet om skillnader och likheter mellan modersmålet och det främmande språket. För de flesta svenska studenter är franskan kronologiskt sett det andra främmande 
språket, vilket gör att även det första främmande språket (oftast engelskan) borde kunna ses som en tillgång (Bardel 2016: 132).

Kommunikativ språkundervisning har många förtjänster, men vi kan inte bortse från det faktum att franskan har en ställning som främmandespråk i Sverige (ett språk som man lär sig i en miljö där språket normalt sett inte talas). Tiden i lärosal är begränsad och att utifrån dessa förutsättningar dogmatiskt hålla fast vid idén att modersmålet (och därmed översättning) inte på några villkor får användas i undervisningen kan ifrågasättas (Hedström 2001). Flera forskare menar att det i själva verket saknas tydliga empiriska belägg för att undervisning endast på målspråket är det bästa för studenterna (Cook 2010; Källqvist et al. 2017).

Vi konstaterade ovan att översättningen har varit på tillbakagång och kopplade detta till den kommunikativa språkundervisningen. Att det finns universitetsutbildningar i språk som är helt fria från översättning kan även ses som en konsekvens av ett samhälle i förändring; till universiteten söker fler och fler studenter som inte har svenska som modersmål, eller som kanske inte alls behärskar svenska. Enligt statistik från Skolverket (www. skolverket.se) var en dryg fjärdedel av alla elever i grundskolan berättigade till modersmålsundervisning läsåret 2015/2016. Denna siffra har på kort tid ökat markant. Även lärarna har, oftare nu än tidigare, ett annat språk än svenska som modersmål. I detta ljus är det givetvis legitimt att ifrågasätta förekomsten av övningar som inbegriper översättning till eller från svenska. Varför ska t.ex. en lärare med franska som modersmål låta en student med spanska som modersmål översätta texter från svenska till franska inom ramen för en kurs i franska?

Att man kan ifrågasätta översättningsövningar mellan vissa språkpar för vissa studenter inom ramen för en viss kurs utgör emellertid inte ett argument för att helt avskaffa all form av översättning som pedagogiskt verktyg. Om studenterna inte delar samma modersmål begränsas möjligheterna och nyttan med översättning, men den utesluts inte. Cook (2010: 151-153) föreslår olika översättningsövningar som kan användas även i studentgrupper som inte delar samma modersmål. Ohlander (2001) efterlyser en ökad multikontrastiv medvetenhet hos lärarna för att bättre hjälpa studenter med annat modersmål än svenska. Ohlanders uppmaning kan uppfattas som över 
hövan ambitiös, men innebär samtidigt ett erkännande av modersmålets betydelse i inlärningen och undervisningen av främmande språk.

\section{2 Översättningsanalys som ämne för examensarbeten Olof Eriksson}

Översättning har historiskt sett intagit en framträdande plats i svensk universitetsundervisning i språk. Översättningsundervisningen var ett färdighetsmoment, vars primära syfte var att förbättra de studerandes skriftliga språkfärdighet men som också användes som ett instrument för att testa denna språkfärdighet. I skolan var översättningens ställning än starkare. Man kan till och med hävda att den där utgjorde det dominerande inslaget i språkundervisningen, framför allt som färdighetstest. Så var t.ex. ännu i slutet av 60-talet alla prov som gavs på gymnasiets nyspråkliga gren - inklusive studentexamensprovet - utformade som tvådelade översättningstexter, vars första del skulle översättas till modersmålet (version) och andra till det främmande språket (tema). Läromedel för denna undervisning utgjordes av så kallade "stilsamlingar", vilka producerades i ganska stor omfattning, för skol- såväl som för universitetsbruk. Den senaste - sista? - av det senare slaget utkom så sent som 1996 (Hansén 1996).

Vid universiteten gavs översättningskurser med efterföljande examination i form av översättningsprov på alla grundutbildningens nivåer. Detta är fortfarande fallet vid vissa lärosäten och i vissa språk. Om den stora betydelse som översättningen tillmättes vid svenska lärosäten ännu några år in på 2000-talet vittnar det faktum att även forskarutbildningen i språk kunde omfatta en obligatorisk och poänggivande översättningskurs med tentamen i form av ett översättningsprov. Detta var t.ex. fallet i forskarutbildningen i franska vid Göteborgs universitet.

Översättningens roll som undervisningsform och testform i färdighetsbefrämjande syfte är omdiskuterad och i hög grad ifrågasatt (Källkvist 2004; Jönsson 2011; Tornberg 2015). Den anses ofta ineffektiv som inlärningsmetod och något förlegad med sitt ensidiga fokus på skriftlig språkproduktion på bekostnad av muntlig kommunikation. Som en konsekvens av detta praktiseras översättningsundervisning i allt mindre utsträckning i svensk språkutbildning. 
På ett helt annat sätt förhåller det sig med översättningens roll i de många översättarutbildningar som idag finns i Sverige (Englund Dimitrova 2013). Här utgör inte översättningen ett medel för att förvärva ökad kunskap om det aktuella språkets grammatik och lexikon och för att förbättra sin skriftliga språkfärdighet i detta språk, utan ett mål i sig, nämligen att på målspråket producera översättningstext som grammatiskt, lexikaliskt, pragmatiskt och stilistiskt så nära som möjligt motsvarar originaltextens egenskaper i dessa avseenden (Ingo 1991, 2009).

Om praktisk översättning som färdighetsmoment numera således är ett sparsamt förekommande inslag i svensk språkutbildning på såväl skol-som universitetsnivå, kan inte detsamma sägas gälla teoretisk översättningsanalys vad beträffar den senare nivån. Det är visserligen sant att översättningsanalys som undervisningsform är sällsynt vid svenska lärosäten. Beklagligtvis, måste man säga, eftersom analys av redan existerande översättningar enligt min mening erbjuder en inlärningsmetod som är väl så effektiv som regelrätt översättning: Kontrastiv analys av text i original (källspråkstext) och i översättning (målspråkstext) gör på ett tydligare sätt än egen översättning den studerande uppmärksam på målspråkets strukturella egenskaper med avseende på grammatik och lexikon. Översättningsanalysens effektivitet beror på att den fokuserar just de punkter där de båda språken uppvisar skillnader av systematisk karaktär - dvs. skillnader som har sin grund i systembundna egenskaper i respektive språk - och som är av speciellt stor vikt för inlärningsprocessen. Försök med översättningsanalys i språkinlärningssyfte har förekommit, bl.a. på 80-talet i franska vid Institutionen för romanska språk i Göteborg, då med utgångspunkt i ett (opublicerat) läromedel med titeln Kontrastiv Antologi (Lindvall \& Eriksson 1989).

Däremot är översättningsanalys numera mycket vanligt förekommande som ämnesområde för uppsatser på kandidat-, magister- och masternivå. Från att tidigare nästan inte alls ha förekommit har uppsatser med översättningsvetenskaplig inriktning under de senaste 30-35 åren blivit allt vanligare vid svenska språkinstitutioner, inte minst inom franskämnet, framför allt med utgångspunkt i litterär text och oftast med franskan som målspråk, men ibland också med analys i motsatt riktning. Jag har själv som handledare och examinator praktiserat denna ämnesinriktning i stor skala vid Göteborgs universitet (1979-1996), vid Åbo Akademi (1996-1997) 
(i form av s.k. pro gradu-avhandlingar, nivåmässigt närmast motsvarande svenska masteruppsatser) och vid Linnéuniversitetet (1998-2012). Vid detta senare lärosäte var till uppsatsarbetet kopplad en teori- och metodkurs, vars syfte var att förbereda skribenterna för uppsatsarbetet genom att bibringa dem elementära kunskaper om översättningsteori och översättningsmetodik.

Översättningsanalytiska uppsatsämnen erbjuder, enligt min mening, flera fördelar i förhållande till den typ av ämnen som traditionellt dominerat produktionen av uppsatser med språkvetenskaplig inriktning vid Sveriges universitet och högskolor. Det största problemet med dessa ämnesval var att de är för allmänt hållna i sin formulering och att uppsatserna därmed tenderar att innehållsmässigt bli alltför omfattande, att "greppa över för mycket". Ett ämne av typen Konjunktiven i franskan riskerar mycket starkt att bli enbart refererande snarare än analyserande, beroende dels på att teoribildningen på området är för stor för att kunna omfattas av en uppsats på grundnivå, dels på att alla aspekter av det franska konjunktivbruket utförligt behandlats i den vetenskapliga litteraturen på området. En sådan uppsats kan följaktligen inte tillföra forskningen någonting som skulle kunna betecknas som "nytt" beträffande bruket av konjunktiv i franskan. Dessutom blir med nödvändighet det exempelmaterial som uppsatsen bygger på - dess korpus - alltför begränsat för att skribenten skall kunna säga något $\mathrm{i}$ ämnet som är strukturellt signifikativt, dvs. något som utgör ett faktum beträffande en systeminherent egenskap i det franska språket. Med andra ord kan en sådan uppsats, i beaktande av premisserna, inte tänkas uppnå någon högre grad av det man kan kalla för "vetenskaplighet" och inte heller möjliggöra för dess författare att ådagalägga någon egentlig "självständighet" i sitt uppsatsarbete (Eriksson 2011).

Översättningsanalys, å andra sidan, ger möjlighet till specifika och väl avgränsade ämnesval som ryms inom ramen för vad som gäller för språkuppsatser på grundnivå beträffande arbetsinsats och tidsåtgång. Översättningsanalytiska ämnen har dessutom den fördelen att de tillåter skribenten att tillföra något nytt och personligt på grundval av en inte särskilt omfattande teoriinläsning och utifrån ett relativt begränsat exempelmaterial. Denna fördel är till stor del en effekt av översättningsvetenskapens natur, eftersom denna disciplin sätter översättningsprocessen - eller den text som är produkten av processen - och den enskilda översättarens roll i denna process i centrum, 
detta till skillnad från den kontrastiva språkvetenskapen, som sysslar med jämförelser mellan språk med avseende på egenskaper som är systembundna - och följaktligen översättaroberoende - i de berörda språken (Eriksson 2004, 2015). Medan översättningsvetenskapen således är textbaserad, är den kontrastiva språkvetenskapen språkbaserad. Undersökningar av detta senare slag kräver stora och varierade korpusar för att uppfylla kravet på kontrastiv signifikans och dessutom kräver de omfattande inläsning på den vetenskapliga litteratur som behandlar det eller de språkliga fenomen som är föremål för studien. Kontrastiv språkanalys, till skillnad från översättningsanalys, lämpar sig således illa som ämnesområde för uppsatser med språkvetenskaplig inriktning.

Jag ger avslutningsvis några exempel på översättningsanalytiska uppsatsämnen som jag föreslagit under loppet av de ca 35 år som jag fungerat som handledare och examinator i ämnet franska:

1. Undersökningar av översättningsstrategier hos enstaka översättare av litterär text med avseende på specifika fenomen som vållar översättningsproblem. Det kan röra sig om fenomen som slang, dialekt, bildspråk, idiom, individuella stildrag (Eriksson 2002), kulturspecifika ord/uttryck (Svane 2002; Tegelberg 2007). Ett enda litterärt verk i svenskt original och i fransk översättning kan räcka som korpus för en sådan uppsats.

2. Undersökningar av hur litterär förstaöversättning förhåller sig till nyöversättning (Tegelberg 2011; Eriksson 2012) utifrån en komparativ analys av två eller flera översättningar till franska av ett och samma svenska litterära verk. Här kan det också vara fråga om översättningar i motsatt riktning. Exempelvis har verk av författare som Balzac, Flaubert, Maupassant, Zola utkommit i svensk nyöversättning vid ett flertal tillfällen.

3. Komparativa undersökningar av "översättarprofil" hos två eller flera översättare på det litterära området utifrån ett antal variabler som bedömts som speciellt relevanta för jämförelsen i fråga (Gullin 1998).

4. Undersökningar av fenomenet "översättningsspråk", dvs. det språk som är en effekt av att översättaren omedvetet genom interferensverkan låter sig påverkas av originaltextens språk, både lexikalt och grammatiskt. Det har t.ex. visats (Gellerstam 1986, 1996) att "översättningssvenska” mycket radikalt och systematiskt skiljer sig från "originalsvenska”. Exempelvis 
är ett verb som anlända mycket vanligare i svensk översättningstext än i svensk originaltext, detta på grund av påverkan från engelskans arrive och franskans arriver. "Översättningsspråk" är utan tvekan ett översättarbetingat - dvs. språkoberoende - fenomen.

\section{3 Översättningsvetenskaplig forskning inom romanska språk} Cecilia Alvstad och Elisabeth Bladh

Att hävda att översättningsforskning generellt sett är särskilt representerad bland forskare i något av de romanska språken vore kanske aningen missvisande. Däremot är det slående hur dominerande aktiviteten inom disciplinen varit på senare tid från forskare med inriktning mot franska, något som framgår i en nyligen gjord sammanställning av svensk översättningsforskning (Englund Dimitrova 2017). Slagsidan mot franska framgår tydligt i diagram 1 och tabell 1 nedan.

Diagram 1. Avhandlingar med översättningsvetenskaplig inriktning vid svenska universitet under perioden 1986-2015 fördelade på forskarutbildningsämnen (Källa: Englund Dimitrova 2017) $)^{94}$

Forskarutbildningsämnen

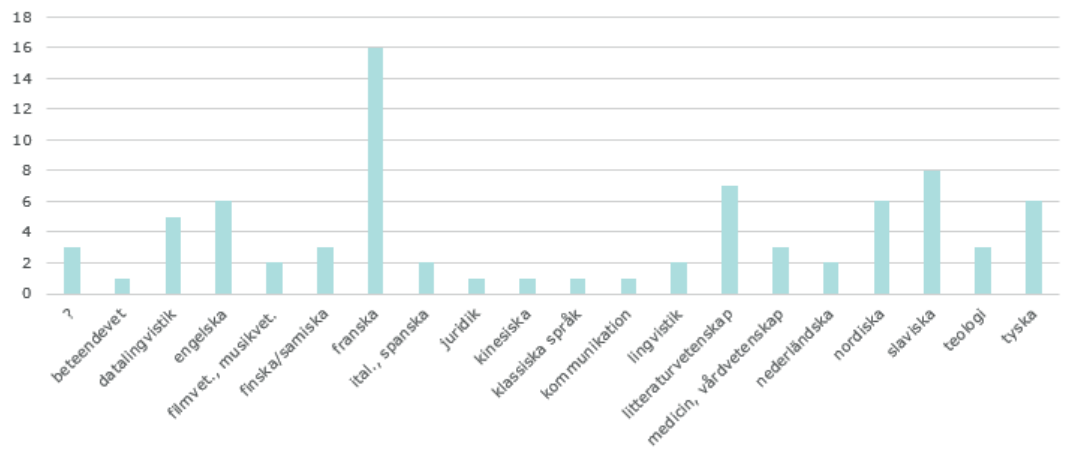

Av sammanlagt 70 avhandlingar med översättningsvetenskaplig inriktning utgör de som lagts fram inom ämnet franska (16 st) snudd på en fjärdedel av den totala andelen och avviker markant från övriga forskarutbildningsämnen. I själva verket är avvikelsen ännu större eftersom åtminstone två

94 För att få en mer rättvisande bild av hur fördelningen ser ut bland de romanska språken valde Englund Dimitrova att redovisa franska separat från italienska och spanska även i det fall avhandlingen lagts fram inom ramen för en forskarutbildning i romanska språk. 
avhandlingar i franska inte räknats med i statistiken då dessa inte haft med "översättning" som nyckelord, vilket utgjort grunden för Englund Dimitrovas statistik. Detta innebär att de franska avhandlingarna till antalet är mer än dubbelt så många som avhandlingarna i slaviska språk, dvs. det ämne som intar silverplatsen i den efterföljande klungan. I andra romanska språk har det bara kommit två avhandlingar, en i spanska (Alvstad 2003) och en i italienska (Svensson 2005), bägge från Göteborg.

En stor del av avhandlingarna i franska består av kontrastiva studier där användningen av något språkligt fenomen jämförs mellan franska och svenska. Den här kontrastiva forskningen baserad på översättningskorpusar blommade upp under 2000-talet och resulterade i ett flertal avhandlingar framförallt i Göteborg under Lars Lindvalls handledning (Kortteinen 2005; Svensson 2005; Ramnäs 2006), i Växjö av den förres adept Olof Eriksson (Jansson 2006; Mossberg 2006; Fohlin 2008), samt i Uppsala (Andersson 2004; Svensson 2010; Hellqvist 2015). Den första avhandlingen med kontrastiv inriktning verkar ha lagts fram i Lund (Sandberg 1997), men följdes inte av flera vid lärosätet. Av dessa 10 avhandlingar undersöker majoriteten språkparet franska-svenska och det enda undantaget utgörs av Svenssons italiensk-svenska studie.

Här ser man också vikten av enskilda personer: Lars Lindvall (Göteborg), Olof Eriksson (Växjö) och Kerstin Jonasson (Uppsala) som lyckats förmedla intresset för översättningsvetenskapliga studier. Dock har ingen av dem själva skrivit en avhandling med koppling till översättningsvetenskap eller kontrastiv lingvistik. Utöver Olof Eriksson, som hör till några av de riktigt produktiva författarna i ämnet översättningsvetenskap, har de inte heller i någon större utsträckning publicerat i ämnet i bokform.

Tabell 1. Forskare verksamma vid svenska universitet som författat eller varit redaktör för översättningsvetenskapliga publikationer i bokform 1986-2015

(Källa: Englund Dimitrova 2017)

\begin{tabular}{l|l}
6 verk eller fler & $\begin{array}{l}\text { L. Kleberg, C. Wadensjö, B. Englund Dimitrova, } \\
\text { O. Eriksson, H. Åkerström }\end{array}$ \\
\hline 5 verk & C. Alvstad, C. Heldner, L. Wollin \\
\hline 4 verk & K. Aijmer, E. Bladh, B. Svane, A. Uggla \\
\hline 3 verk & $\begin{array}{l}\text { B. Arapović, B. J. Epstein, Y. Lindqvist, G. Magnusson, } \\
\text { E. Teodorowicz-Hellman, S. Torgerson, I. Ågren/Lysén }\end{array}$
\end{tabular}


I tabell 1 framgår att forskare i romanska språk (markerade i fet stil), och då framförallt franska (markerade i fetstil och understrykning) är väl representerade bland produktiva svenska översättningsvetare.

I likhet med den forskning som bedrivs internationellt är ämnesvalen mycket varierande och utöver ovanstående fall gällande kontrastiv lingvistik förefaller det inte som om en särskild forskare har skapat skola. Spännvidden är stor och omfattar såväl barn- och ungdomsöversättning som bibelöversättning, litteraturförmedling, undertextning, teknisk översättning, litterär översättning och inte minst de redan nämnda kontrastiva språkstrukturella undersökningarna (jfr Englund Dimitrova 2014).

Hur står sig då den översättningsvetenskapliga forskningen inom den svenska romanistiken internationellt? Dessvärre citeras bidragen från svenska romanister sällan internationellt och en av förklaringarna till detta skulle kunna vara att de romanska översättningsvetarna och kontrastivisterna verksamma i Sverige, i motsats till vad som varit fallet inom språkinlärningsforskningen, inte övergått till att företrädesvis publicera sig på engelska. Om man undersöker publikationslistor av några av de mer framträdande forskarna inom ämnesområdet (t. ex. Olof Eriksson och Kerstin Jonasson) visar det sig raskt att bidragen på engelska utgör en mycket begränsad del av deras vetenskapliga produktion. En av förklaringarna till detta är troligen att det av naturliga skäl ansetts - och fortfarande anses - viktigt att publicera på det romanska språk man forskar inom. På så vis interagerar man med andra romanister och skapar en starkare förankring till det språk-, litteratur- och kulturområde man är expert på. Samtidigt dominerar engelskan starkt inom det översättningsvetenskapliga forskningsfältet. De enda ledande internationella tidskrifterna inom fältet som tar in bidrag på romanska språk är Meta: journal des traducteurs (Érudit) och Babel: Revue internationale de la traduction/International Journal of Translation (John Benjamins), medan Target (John Benjamins), Perspectives: Studies in Translation Theory and Practice, The Translator och Translation Studies (samtliga Taylor \& Francis) och Across Languages and Cultures enbart tar in bidrag på engelska. Bland tidskrifter med mindre internationell prägel som tar in bidrag på romanska språk bör nämnas Quaderns: revista de traducció, TRANS: Revista de traducción och Palimpsestes men även i dessa återfinns få bidrag från svenska romanister. 
Romanister hamnar således i en klämsko. Å ena sidan måste det anses viktigt att doktorander lär sig skriva på det romanska språket de ska undervisa i och forska om. Å andra sidan är internationell publicering på engelska idag en förutsättning om forskningen ska nå ut internationellt och forskaren ska kunna delta i ett vidare samtal inom disciplinen. Detta handlar om så mycket mer än om ovan nämnda citering. Den kvalitetsgranskning och kvalitetshöjning som förekommer i samband med granskningsprocesser av bidrag är också viktig.

Inom romanistiken i Sverige skrivs de flesta avhandlingar fortfarande på det romanska språket. I Norge går däremot allt fler över till att skriva på engelska. Fördelar med detta kan vara bredare jobbmöjligheter då fler potentiella arbetsgivare har möjlighet att läsa arbetet, men också större möjlighet att få kommentarer på utkast under arbetets gång (forskargrupper, granskning av artikelmanus etc.). Fördelar för institutionen kan vara en bredare möjlighet att följa upp fall där det uppstår problem och att välja opponent vid disputation. Bland de uppenbara nackdelarna bör nämnas att inte bara något av romanistikens identitet riskerar att gå förlorad utan att kompetens att skriva akademisk text på romanska språk också kan gå förlorad. Detta kan i sin tur vara problematiskt inte minst i ett undervisnings- och handledningsperspektiv om vi fortfarande förväntar oss att studenter ska skriva sina C- och D-uppsatser på språken i fråga.

Den tid när romanister framförallt skrev för en publik av andra romanister måste nog anses vara förbi. I och med den ökande graden av specialisering inom de språk- och litteraturvetenskapliga ämnena är det idag snarare inom underdisciplinerna som dagens svenska forskare har sin primära vetenskapliga hemvist. Det kan exempelvis röra sig om pragmatik, diskursanalys, språkinlärning, narratologi, receptionsstudier eller den disciplin som diskuteras här, översättningsvetenskap. Vikten av att samtidigt verka i ett romanistsammanhang ska emellertid på intet sätt underskattas eftersom det öppnar upp för dialog med forskare inom andra (under)discipliner: språk- och kulturområdet som gemensam nämnare möjliggör att gränser mellan (under)discipliner överskrids. Detta kan ge näring åt nya spännande utvecklingslinjer inom såväl forskning som undervisning inom romanistiken. 


\section{Bibliografi}

Bardel, Camilla, 2016: De romanska språken som L3. I: Bardel, Camilla, Falk, Ylva \& Lindqvist, Christina (red.), Tredjespråksinlärning. Lund: Studentlitteratur. 115-135.

Butzkamm, Wolfgang, 2003: We only learn language once. The role of the mother tongue in FL classrooms: death of a dogma. Language Learning Journal 28. 29-39.

Cook, Guy, 2010: Translation in Language Teaching. Oxford: Oxford University Press.

Englund Dimitrova, Birgitta, 2007: Tjugo år av svensk översättningsvetenskap. I: Lindqvist, Yvonne (red.), Gränslös översättning. Uppsala: Hallgren \& Fallgren. 13-31.

Englund Dimitrova, Birgitta, 2013: Översättarutbildningar i Sverige. I: Från ett språk till ett annat. Om översättning och tolkning. (Språkrådet.) Stockholm: Norstedt. 66-70.

Englund Dimitrova, Birgitta, 2014: Svensk översättningsvetenskap 1986-2009. Publikationer i bokform eller som elektronisk resurs. Opublicerat manus tillgängligt på författarens sida på Academia.edu

Englund Dimitrova, Birgitta, 2016: Svensk översättningsvetenskap 2010-2015 (med kompletteringar för åren 1986-2009). Publikationer i bokform eller som elektronisk resurs. Preliminär version. Opublicerat manus tillgängligt på författarens sida på Academia.edu

Englund Dimitrova, Birgitta. 2017: 30 år av översättningsvetenskap i Sverige. Presentation vid Tolk- och översättarinstitutets 30-årsjubileum. Stockholms universitet. 25 november.

Eriksson, Olof, 2002: Stil och översättning. Pär Lagerkvists prosastil ur franskt översättningsperspektiv. (Acta Wexionensia 19.) Växjö: Växjö University Press.

Eriksson, Olof, 2004: Entre traductologie et linguistique contrastive. La notion de 'transposition'. I: Härmä, Juhani \& Tuomarla, Ulla (red.), Actes du $\sigma e$ colloque franco-finlandais de linguistique contrastive. (Publications du Département des Langues Romanes de l'Université de Helsinki 15.) Helsinki. 88-103.

Eriksson, Olof, 2011: Vetenskaplighet, självständighet, färdighet. En utvärdering av examensarbeten $i$ de moderna spräken (engelska, franska, spanska, tyska) vid Institutionen för språk och litteratur, Linnéuniversitetet. (Opublicerad rapport.) Växjö: Linnéuniversitetet. 33 sidor.

Eriksson, Olof (red.), 2012: Aspekter av litterär nyöversättning - Aspects de la retraduction littéraire. Föredrag från ett symposium vid Linnéuniversitetet (Växjö) 7-8 oktober 2011. Växjö: Linnaeus University Press. 
Eriksson, Olof, 2015: Kontrastiv språkforskning på översättningsanalytisk grund - exemplet presens particip. Språk och stil 25. 38-68.

Gellerstam, Martin, 1986: Translationese in Swedish novels translated from English. I: Wollin, Lars \& Lindquist, Hans (red.), Translation Studies in Scandinavia. Lund: Gleerup. 88-95.

Gellerstam, Martin, 1996: Translations as source for cross-linguistic studies. I: Aijmer, Karin, Altenberg, Bengt \& Johansson, Mats (red.), Languages in Contrast. (Lund Studies in English 88.) Lund: Lund University Press. 53-62.

Gullin, Christina, 1998: Översättarens röst. En studie i den skönlitteräre översättarens roll med utgångspunkt i översättningar av Else Lundgren och Caj Lundgren. (Litteratur Teater Film, Nya serien 18.) Lund: Lund University Press.

Hansén, Iah, 1996: Franska stilar för universitetet. Malmö: Gleerup.

Hedström, Karl, 2001: Grammatikinlärning. I: Ferm, Rolf \& Malmberg, Per Språkboken: en antologi om språkundervisning och språkinlärning. Stockholm: Statens skolverk. 69-79.

Ingo, Rune, 1991: Från källspråk till målspråk. Introduktion i översättningsvetenskap. Lund: Studentlitteratur.

Ingo, Rune, 2009 [2007]: Konsten att översätta: översättandets praktik och didaktik. Lund: Studentlitteratur.

Jönsson, Anna, 2011: Översättning som effektiv undervisningsmetod. En litteraturstudie. (Opublicerat examensarbete $15 \mathrm{hp}$.) Linköping: Linköpings universitet (Institutionen för Kultur och Kommunikation).

Källkvist, Marie, 2004: The Effect of Translation Exercises versus Gap-exercises on the Learning of Difficult L2 Structures. I: Malmkjær, Kirsten (red.), Translation in Undergraduate Degree Programming. Amsterdam: John Benjamins. 163-184.

Källqvist, Maria, Gyllstad, Henrik, Sandlund, Erica \& Sundqvist, Pia, 2017: English Only in Multilingual Classrooms?. Lingua 4. 27-31.

Lindvall, Lars \& Eriksson, Olof, 1989: Kontrastiv Antologi. 20 svenska texter med franska översättningar. (Opublicerat läromedel.) Göteborg: Göteborgs universitet (Institutionen för romanska språk). 261 sidor.

Nation, I. S. Paul, 2003: The role of the first language in foreign language learning. The Asian EFL Journal 5 (2). 1-18.

Ohlander, Sölve, 2001: Vilka slags ämneskunskaper behöver lärarna i det flerspråkiga klassrummet? Det multikontrastiva perspektivet. I: Ferm, Rolf \& Malmberg, Per, Språkboken: en antologi om språkundervisning och språkinlärning. Stockholm : Statens skolverk. 198-211.

Svane, Brynja, 2002: Hur översätter man verkligheten? (Rapporter från forskningsprogrammet Översättning och tolkning som språk- och kulturmöte, 1.) Uppsala: Uppsala universitet. 
Tegelberg, Elisabeth, 2007: Culturalité, temporalité, spatialité et autres aspects de la traduction littéraire : l'exemple de Jonas Gardell. I: Eriksson, Olof (red.), Översättning och Kultur. Föredrag från ett symposium vid Växjö universitet 17-18 november 2006. (Acta Wexionensia 113.) Växjö: Växjö University Press. 148-191.

Tegelberg, Elisabeth, 2011: Nyöversättning - när, hur och varför?. Tidskrift för litteraturvetenskap 3-4. 77-90.

Tornberg, Ulrika, 2015[1997]: Språkdidaktik. Malmö: Gleerup. 